\title{
Importance of Regional Integration for Economic Development; Comparative Study of ASEAN and SAARC
}

\author{
K.M.Hashan Viraj Wijesinghe \\ Postgraduate Student, Department of International Relations, \\ Faculty of Arts, University of Colombo
}

\begin{abstract}
Today we are living in such a highly complicated and interdependent world where no country can remain isolated. Since the end of the Second World War, regional cooperation and integration has become a common phenomenon across the world. SAARC and ASEAN have been two such regional groupings which have been created with the prime objective of attaining greater economic cooperation and integration. However, in terms of achievements, SAARC and ASEAN remain at completely two different levels. On one hand there is Association of South East Asian Nations (ASEAN), which has made great strides in terms of regional cooperation while there is also South Asian Association for Regional Cooperation (SAARC), whose own future is at doubt. Against this backdrop, the study looks into how well ASEAN has able to perform in terms of regional cooperation and integration, while it also looks into where SAARC has underperformed with special focus on economic cooperation. The main objective of this study is to understand the importance of economic cooperation and integration for economic development. A comparison would make it possible to better understand the dos and don'ts of becoming successful in regional economic integration. This is a desk research based on secondary data. As this study is based on economic aspect of regional integration, it shall take in to consideration aspects like trade volumes, investments and tourist arrivals etc. the study has underscored the importance of enhancing intra-regional trade, investments and tourism and the role of the leader within a
\end{abstract}


regional entity as the main pillars of intra-regional economic success, while it also calls for the opportunities of initiating inter regional cooperation.

Key words: Regional Integration, ASEAN, SAARC, Economic Development

\section{Introduction}

Today we are living in a highly globalized and sophisticated world where no country can remain isolated. Thus, regional cooperation and regional integration have occupied greater prominence and relevance in contemporary world politics. Especially since 1945, the number of regional grouping or organizations grew significantly. Regional cooperation has been identified as one of the main strategies which can be used to solve common political, economic, scientific and socio-cultural issues faced by countries in a particular geographical area. Looking at various regional organizations which are there today, we can observe that the formation of regional set ups has been greatly successful in bringing historically hostile countries on a common platform. The classic example for this would be the European Union (EU). According to Chowdhury \& Mamta, cooperation among the neighbors not only strengthen the economic and financial sectors via optimal utilization of natural and human resources but also enhances greater political stability and social and cultural cooperation between member nations (2005, p.24). Looking at the overall performance of any regional organization, statistics show that the establishment of such organizations has enhanced the volume of trade and investment which have eventually contributed towards greater economic success of the vast majority of countries around the world. Regional economic cooperation occurs in various forms and degrees, and is in general aimed at increasing cross border linkages and deepening interpenetration of economic activity for the mutual benefit of economies within a geographic region (UNCTAD, 2007, p.53). In fact, intra- regional 
trade expansion is one of the efficient ways of integrating to the much larger international economy as the countries become more competitive both in terms of input use and cost effect production of output (Chowdhury \& Mamta, 2005, p.24).

Thus, this particular study shall focus on the economic impact of regional integration. For this purpose, the study shall make a comparative study of two regional organizations, namely, South Asian Association for Regional Cooperation (SAARC) and Association of Southeast Asian Nations (ASEAN). The main rationale behind choosing ASEAN for this study is considering what all major regional set ups have achieved so far, their willingness to work together as a single entity, ASEAN has maintained high standards. Looking at the current situation in the European Union (EU) which was used to consider as the champions of regional integration, its future remains doubtful. Especially with the United Kingdom's decision to leave the EU, the future of the organization is now in uncharted waters. In contrast, ASEAN is marching forwards with great success. Today, ASEAN is the role model we can look into when it comes to regional integration in the developing world. The rationale behind selecting SAARC for the study is multidimensional. First, as a regional grouping, SAARC has not been successful, especially in terms of economic integration. It's more fragile and its own existence has become doubtful. Against this backdrop, on one hand there is ASEAN, a role model for regional integration and on the other hand, there is SAARC, which has not been able to attain the success of regional integration. A comparison would make it understand the dos and don'ts of becoming successful in regional economic cooperation and integration. As given in the topic, this study shall be limited to the economic aspects of regional integration. Regional integration can be attained in both political and economic spheres and such integration could benefit wide areas of 
interests which include political, economic, socio-cultural etc. under economic integration the study shall focus on the inter dependent nature of trade, investments and tourism sectors of economic integration.

\section{Problem Statement}

At its inception, both the regions were facing with very identical issues which include both intra-regional as well as inter-state issues. At those times, both the regions were drenched in suspicion, turmoil and political instability. From an economic perspective, high levels of poverty and unemployment, stagnant economic growth rates, low level of international trade were common to both regions. However, ASEAN has come long way since then. Today the region of Southeast Asia, through ASEAN has able to achieve great economic stability and prosperity showcasing how economic cooperation can benefit both individual states as well as the entire region. On the other, there is SAARC, which is lagging behind in all spheres of regional cooperation. Thus, a comparative study of ASEAN and SARRC would help answer the question how economic cooperation can benefit both individual states as well as the region.

\section{Objectives of the Study}

The main objective of this study will be to analyze, evaluate and understand the importance of regional integration for economic development of both individual states as well as the region as a whole. Apart from that, the study shall also attempt to; (1) Understand how ASEAN has become successful as a regional entity amidst various intra-regional and external issues, (2) Evaluate and understand the reasons for the underperformance of SAARC as a regional organization in the context of achieving economic integration for economic development and (3) Identify 
the opportunities and strategies which SAARC can use to enhance intraregional economic relations which would eventually assist the region to attain great economic success.

\section{Methodology}

This particular study is a comparative study of two regional organizations namely, SAARC and ASEAN. A qualitative research in nature and the data will be collected through secondary means including book, journals, reports, surveys, websites, newspapers etc. As this study is based on economic aspect of regional integration, it shall take in to consideration aspects like trade volumes, investments and tourists arrivals etc. the study shall compare SAARC and ASEAN under these economic criteria, how they have performed in order to understand the level of integration they have attained while it also focuses on the level of impact made by these numbers on the economic development of individual states belong to SAARC and ASEAN in order to understand impact of regional integration on economic development of both individual countries and region as a whole.

\section{Literature Review}

Today, regional integration has occupied a prominent place in world politics. While forms of regional theory were already in existence, specific study of the phenomenon began with a focus on Europe in the early 1950s, shortly after the end of the world war 2 (Kolovos,2010,p.03). Regional economic cooperation occurs in various forms and degrees, and is in general aimed at increasing cross border linkages and deepening interpenetration of economic activity for the mutual benefit of economies within a geographic region (UNCTAD, 2007, p. 53).According to the United Nations Economic and Social Commission for Asia and the Pacific (UNESCAP), regional 
cooperation brings many of the same benefits as multilateralism, but on a small scale. First, it enables participating countries to overcome the small size of their domestic markets and achieve economies of scale and greater specialization in production, thus increasing the competitiveness of their products. Secondly, access to a larger market enables developing countries both to expand existing industries and to set up new export industries, diversifying exports and reducing their vulnerability to setbacks in a specific product market. Thirdly, regional cooperation can enhance the capacity of developing countries to meet emerging challenges, including the application of new technologies. Fourthly, it is increasingly clear that regional trade facilitation measures offer significant benefits by reducing the cost of transactions across international borders and removing non-border obstacles (UNESCAP, 2004, p.24). According to the United Nations Development Program, regional economic integration is much broader than efforts simply to liberalize trade. It can also include investments in regional infrastructure, harmonization of regulations and standards, common approaches to macroeconomic policy, management of shared natural resources, and greater labour mobility (UNDP, 2011, p.03). With regard to the regional integration of ASEAN, strengthening regional ties in Southeast Asia-the potential benefits of larger markets of 570 million people that bring about economies of scale and reduced transaction cost will enhance the competitiveness of the region (Tanaka, 2009, p.02). Making a comparative study of SAARC and ASEAN, Siddika concludes, from regional stability and security, ASEAN is now moving to regional economic integration and cooperation which is another step of their success. Neither in terms of economic cooperation nor in terms of promotion of peace and understanding there have been no signs of regional cooperation in SAARC (2013, p.73) 


\section{Analysis}

Association of Southeast Asian Nations (ASEAN) and South Asian Association for Regional Cooperation are two regional set ups came into existence at different times periods for both identical and different reasons. Looking at ASEAN, which was created in 1967 by its founding members namely, Indonesia, Malaysia, Philippines, Singapore and Thailand came into being at a time when the whole of Southeast Asian region was drenched in political instability, suspicion and insecurity. It was a time when the entire region was overshadowed by a number of severe intra- regional conflicts and domestic upheavals created largely due to communist insurgents. ASEAN's primary purpose was to create an environment by which each state's survival could be ensured through the fostering of regional stability and limiting competition between them (Siddika, 2013, p.72). Today, ASEAN has become one of the most successful regional organizations in the world and undoubtedly the most successful one in Asia. Its membership has expanded to ten with Brunei, Cambodia, Laos, Myanmar and Vietnam also joining the grouping. Today, ASEAN has the $6^{\text {th }}$ largest economy in the world and $3^{\text {rd }}$ largest in Asia, with a combined GDP of US\$ 2.55 trillion. Furthermore, ASEAN share in the world GDP has almost doubled from 3.3\% in 1967 to $6.2 \%$ in 2016. Over the past two decades, ASEAN has been the leader of East Asian trade, economic and security integration. ASEAN has been the only organization constantly focused on regional integration (Kurlantzick, 2012, p.04). ASEAN as a regional grouping is striving to attain the objectives of accelerating the economic growth, social progress and cultural development in the region, promoting regional peace and stability, promoting active collaboration and mutual assistance etc. On the other hand, SAARC, established in 1985 with seven member states namely, Bangladesh, Bhutan, India, Maldives, Nepal, Pakistan and Sri Lanka today has a total 
membership of eight with Afghanistan joining the grouping in 2007. The main objectives of SAARC includes, promoting the welfare of the people of South Asia and improve their quality of life, accelerate economic growth, social progress and cultural development of the region, promote and strengthen collective self- reliance among the countries of South Asia etc. Looking at both of these regional groupings, the objectives are more or less the same. Moreover, being geographically located with close proximity (Image 1) both the regions encounter similar economic issues like poverty, unemployment etc.

\section{Image 1: Geographical location of South Asia and Southeast Asia.}

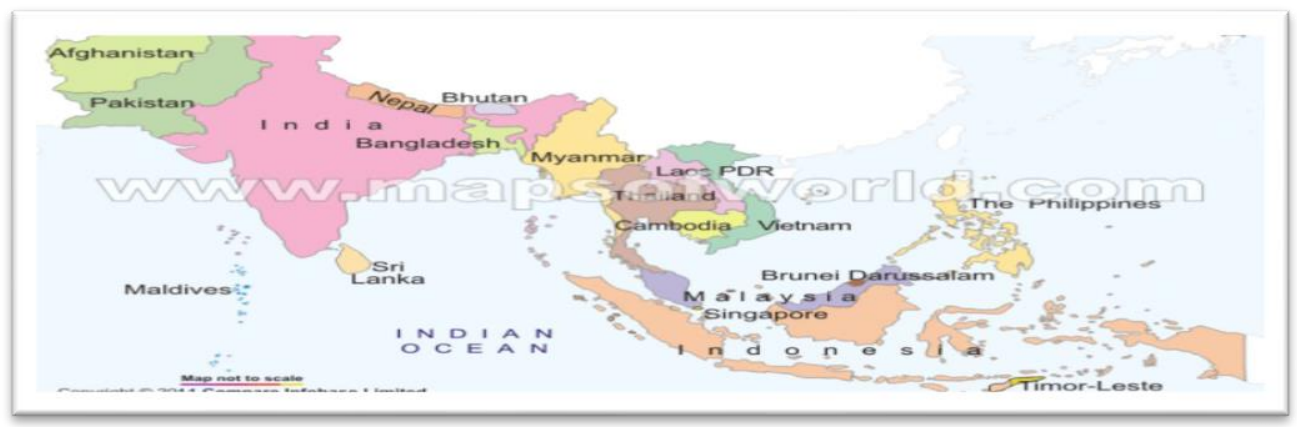

Source: http://mrethiergeo.weebly.com/south--southeast-asia.html

However, the level of economic success attained by these regional groupings has vast differences. While ASEAN has attained so much success in terms of economic integration, SAARC's progress is not any means satisfactory. Comparing the economic statistics, especially trade, investments and tourism, ASEAN has performed, exceptionally well compared to SAARC. As given in the Table 1, compared to SAARC, ASEAN has performed well or rather outplayed SAARC in terms of intra-regional trade, intra- regional Foreign Direct Investments (FDI) and intra-regional tourist arrivals. 
Table 1: Intra- Regional trade, Investment and Tourist arrivals in SAARC and ASEAN.

\begin{tabular}{|c|c|c|c|c|c|c|c|}
\hline & \multicolumn{2}{|c|}{$\begin{array}{l}\text { Movement in } \\
\text { Trade and } \\
\text { Investment }\end{array}$} & \multicolumn{2}{|c|}{$\begin{array}{l}\text { Movement in } \\
\text { Capital }\end{array}$} & \multicolumn{3}{|c|}{ People movement } \\
\hline & $\begin{array}{c}\text { Trade } \\
(\%) \\
2016\end{array}$ & $\begin{array}{l}\text { FDI } \\
(\%) \\
2016\end{array}$ & $\begin{array}{c}\text { Equity } \\
\text { Holdin } \\
\text { g }(\%) \\
2016 \\
\end{array}$ & $\begin{array}{c}\text { Bond } \\
\text { Holding } \\
(\%) \\
2016 \\
\end{array}$ & $\begin{array}{c}\text { Migratio } \\
\text { n } \\
(\%) \\
2015 \\
\end{array}$ & $\begin{array}{c}\text { Tourism } \\
(\%) \\
2015\end{array}$ & $\begin{array}{l}\text { Remittanc } \\
\text { s }(\%) 2016\end{array}$ \\
\hline \multicolumn{8}{|c|}{ Within Sub Regions } \\
\hline $\begin{array}{l}\text { Southeas } \\
\text { t Asia }\end{array}$ & 22.8 & 23.7 & 7.4 & 7.9 & 34.1 & 69.5 & 14.3 \\
\hline $\begin{array}{l}\text { South } \\
\text { Asia }\end{array}$ & 5.8 & 0.6 & 0.3 & 2.2 & 26.2 & 11.9 & 9.2 \\
\hline
\end{tabular}

Source: Created by Author based on Asian Economic Integration Report 2017- Asian Development Bank

Graph 1: Intra regional trade of SAARC and ASEAN as percentage of total trade

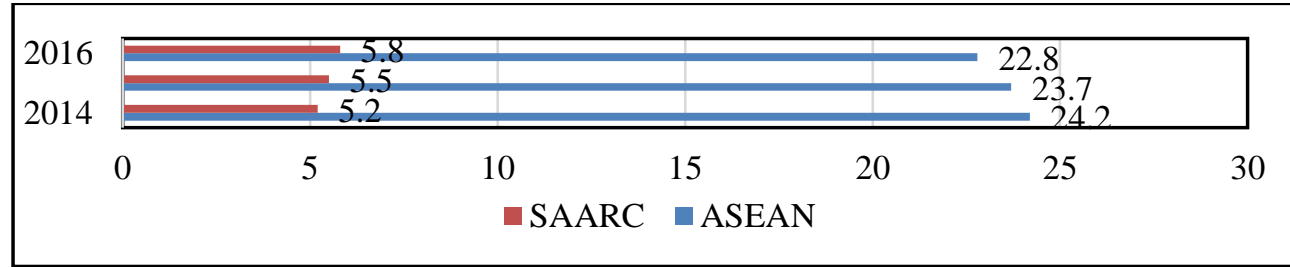

Source: Created by Author based on Asian Economic Integration Report 2017- Asian Development Bank

Graph 2: Intra regional investment of SAARC and ASEAN as a percentage of total investment inflows.

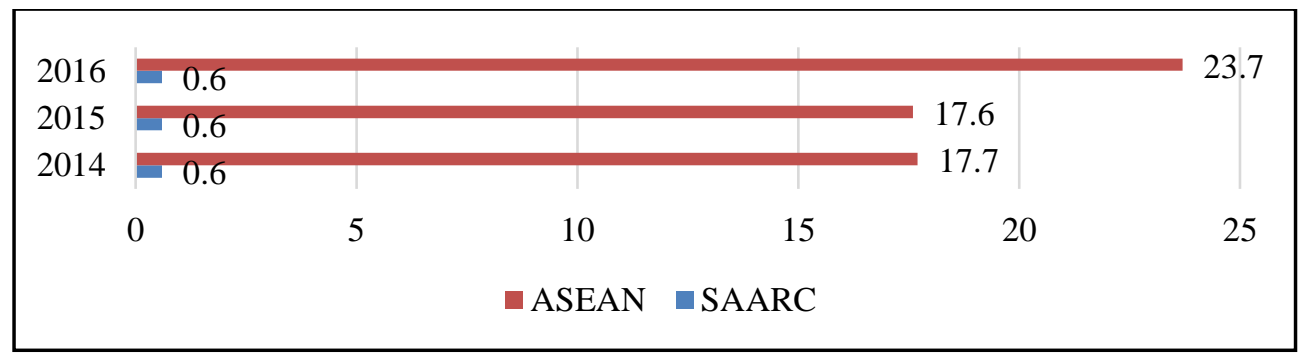

Source: Created by Author based on Asian Economic Integration Report 2017- Asian Development Bank 
As given in Table 1, the volume of intra-regional trade as a percentage of total trade in Southeast Asia in 2016 stood 22.8\% while the corresponding figure for SAARC was just $5.8 \%$. Here what matters is the consistency. Looking at graph 01, intra-regional trade continues to remain at a consistent position. In other world over the last few years, more than 1/5 of Southeast Asian trade has been intra-regional. When it comes to intra-regional investments also ASEAN is far ahead of SAARC. Looking at the statistics, the volume of intra-regional investments as a percentage of total investments in Southeast Asia in 2016 was $23.7 \%$ while the corresponding figure for South Asia was under $1 \%$.

When it comes to trade, the intra-regional trade among the ten Southeast Asian countries is defined and shaped by the ASEAN Free Trade Area (AFTA) which was signed in 1992 ASEAN Summit in Singapore, while South Asian Free Trade Area (SAFTA) which was signed in 2006, replacing South Asian Preferential Trade Agreement (SAPTA) plays the main role in enhancing trade in South Asia. Going back to ASEAN FTA, it is important to understand how individual states are been benefitted through enhanced intra-regional trade relations.

Table 2: Top 10 export partners of Thailand 2016

\begin{tabular}{|l|c|c|}
\hline \multicolumn{1}{|c|}{ Country } & Export Volume (US\$ Billion) & \% of total Thai exports \\
\hline United States & 24.4 & 11.4 \\
\hline China & 23.6 & 11 \\
\hline Japan & 20.4 & 9.6 \\
\hline Hong Kong & 11.4 & 5.3 \\
\hline Australia & 10.2 & 4.8 \\
\hline Malaysia & $\mathbf{9 . 5}$ & $\mathbf{4 . 5}$ \\
\hline Vietnam & $\mathbf{9 . 3}$ & $\mathbf{4 . 4}$ \\
\hline Singapore & $\mathbf{8}$ & $\mathbf{3 . 8}$ \\
\hline Indonesia & $\mathbf{8}$ & $\mathbf{3 . 8}$ \\
\hline Philippines & $\mathbf{6 . 4}$ & $\mathbf{3}$ \\
\hline
\end{tabular}

Source: Workman, D. (2017, February 06). Thailand's Top Trading Partners. Retrieved November 22, 2017, from http://www.worldstopexports.com/thailands-top-import-partners/ 
The above Table 2 indicates the top 10 export partners of Thailand. Looking at the table, out of the top 10 partners of Thailand, five are from the Southeast Asian region (as Bolded) and taking as a whole ASEAN region remains the main export market for Thailand (Table 3). This is a classic example to show how intra-regional trade has a positive impact on the economic success of individual states of the grouping.

Table 3: Top 5 Export destinations of Thailand (growth/share)-2016

\begin{tabular}{|l|l|c|c|}
\hline \multicolumn{1}{|c|}{ No } & \multicolumn{1}{|c|}{ Country/Region } & Amount & Share (\%) \\
\hline $\mathbf{0 1}$ & ASEAN 9 & $\mathbf{5 4 . 7}$ & $\mathbf{2 5 . 4}$ \\
\hline 02 & USA & 24.5 & 11.4 \\
\hline 03 & China & 23.8 & 11.1 \\
\hline 04 & EU (27) & 22.0 & 10.2 \\
\hline 05 & Japan & 20.6 & 9.6 \\
\hline
\end{tabular}

Source: 2016 Economic Review Thailand. (2017); Netherlands Embassy Bangkok

This can be better understood through a comparison with a country which has low level of economic integration.

Table 4: Top 10 export partners of Sri Lanka- 2016

\begin{tabular}{|l|c|c|}
\hline \multicolumn{1}{|c|}{ Country } & $\begin{array}{c}\text { Export volume } \\
\text { (US\$ million) }\end{array}$ & $\begin{array}{c}\text { \% of total Sri } \\
\text { Lankan exports }\end{array}$ \\
\hline United States & 2,810 & 27.3 \\
\hline United Kingdom & 1,044 & 10.1 \\
\hline India & $\mathbf{5 5 4}$ & $\mathbf{5 . 4}$ \\
\hline Germany & 500 & 4.9 \\
\hline Italy & 430 & 4.2 \\
\hline Belgium-Luxembourg & 338 & 3.3 \\
\hline United Arab Emirates & 234 & 2.3 \\
\hline China, People's Republic of & 211 & 2.0 \\
\hline Netherlands & 208 & 2.0 \\
\hline Japan & 202 & 2.0 \\
\hline
\end{tabular}

Source: Central Bank of Sri Lanka Annual Report -2016

The Table 4 indicates the top 10 export partners of Sri Lanka in 2016. Looking at the main export partners of Sri Lanka, there is only one country 
from the region of South Asia (India). Looking at a glance, compared to Thailand, Sri Lanka has low level of intra-regional trade. Furthermore, according to the Central Bank, Sri Lanka's total value of exports to SAARC region remains only $8 \%$ of its total trade. Strengthening intra-regional trade has a number of advantages for an economy. To begin with, it essentially increases the volume of trade. Secondly, it diversifies the export markets. Comparing Thailand and Sri Lanka, out of the latter's total exports, more than $1 / 3$ goes to two countries. However, on the other hand, strengthened intra-regional trade has helped Thailand to diversify its export markets. The benefits of promoting intra-regional trade are reflected by the continuous growth in the export sector of Thailand (Graph 03).

\section{Graph 03: Thailand merchandise trade with world. (Euro billion)}

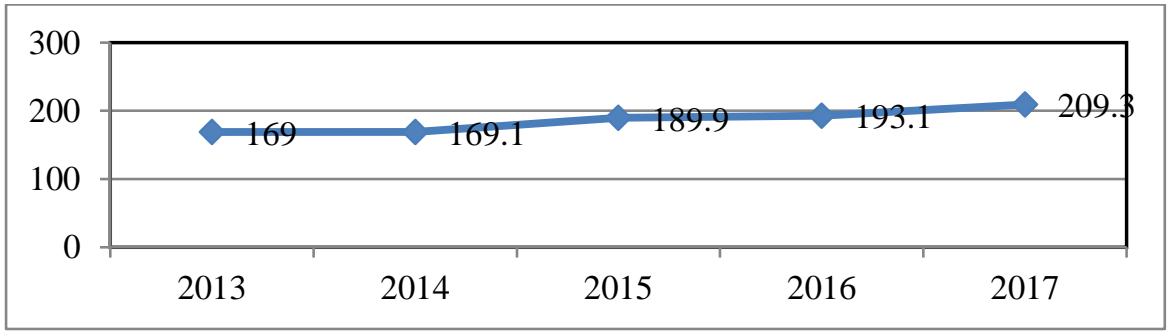

Source: European Commission Directorate General for Trade.

As shown in the above graph, the export volumes of Thailand have continued to grow fuelled by the strengthened intra-regional trade.

When it comes to tourism sector also, economic integration plays a critical role. This can be understood by evaluating Indonesia's performance in tourism sector. 


\section{Graph 04: Number of Foreign Visitor Arrivals to Indonesia by Country of Residence, 2011-2014}

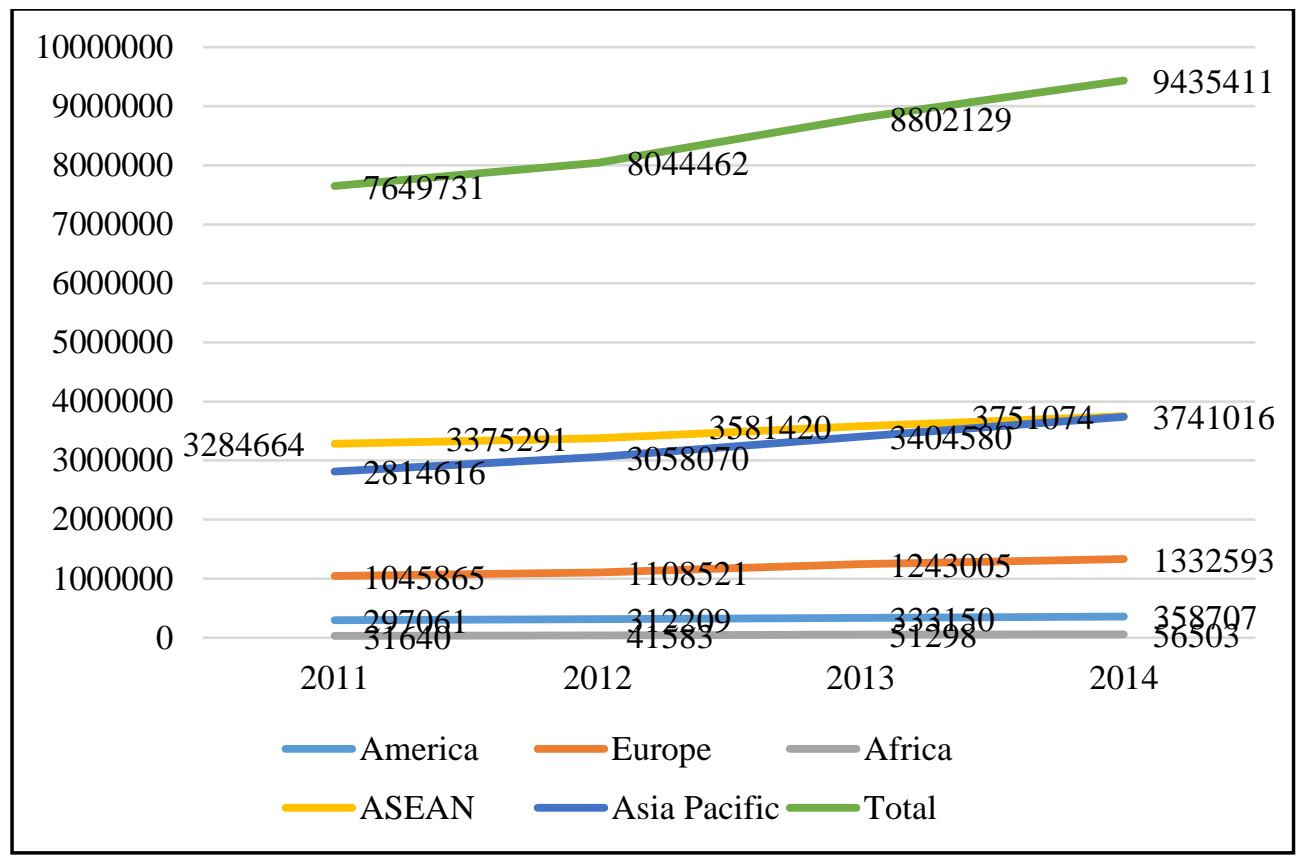

Source: Statistics Indonesia https://www.bps.go.id/linkTabelStatis/view/id/1388

As indicated in the Graph 04, out of the total tourist arrivals of 9.4 million to Indonesia in 2014, 3.7 tourists have come from the ASEAN region. As a whole, ASEAN region is the largest tourists generating region for Indonesia, representing almost $40 \%$ of total tourist arrivals to Indonesia. Today, Indonesia has become a leading tourist destination in the world and its contribution to its economy is immense. For instance, the total contribution of Travel and Tourism to the GDP of Indonesia was USD 57.9 billion (6.2\% of GDP) in 2016 (Table 5), and was forecast to rise by $4.3 \%$ in 2017. As given in the table below, in terms of travel and tourism's total contribution to GDP, Indonesia remains on the top with a value above the world average. 
Table 5: Travel and Tourism's total contribution to GDP -2016 (US\$ Billions)

\begin{tabular}{|l|c|}
\hline \multicolumn{1}{|c|}{ Country } & Value \\
\hline China & 1000.7 \\
\hline India & 208.9 \\
\hline Australia & 136.2 \\
\hline Thailand & 82.5 \\
\hline Philippines & 60.1 \\
\hline Indonesia & $\mathbf{5 7 . 9}$ \\
\hline World Average & 57.3 \\
\hline
\end{tabular}

Source: Travel \& Tourism Economic Impact 2017 Indonesia-World Travel and Tourism Council

It is also important to underscore the success achieved by ASEAN in terms of strengthening its economic ties with the rest of the world. Over the past few years, ASEAN members have proliferated FTAs and broader Economic Partnership Agreements (EPAs) to facilitate trade and investment with key economic partners- and allow firms to boost competitiveness. As shown in Table 06, by the end of 2013, a total of 90 FTAs involving ASEAN countries were either signed, being negotiated or proposed (ADB, 2014, p.18)

Table 06: Status of ASEAN Free Trade Agreements (As of July 2013)

\begin{tabular}{|l|c|c|c|c|}
\hline \multicolumn{1}{|c|}{ Type } & Signed & $\begin{array}{c}\text { Under } \\
\text { Negotiation }\end{array}$ & Proposed & Total \\
\hline Multilateral & 9 & 5 & 4 & 18 \\
\hline Plurilateral & 2 & 10 & 3 & 15 \\
\hline Bilateral & 29 & 14 & 14 & 57 \\
\hline Total & $\mathbf{4 0}$ & $\mathbf{2 9}$ & $\mathbf{2 1}$ & $\mathbf{9 0}$ \\
\hline
\end{tabular}

Source: ASEAN 2030: “Toward a Borderless Economic Community"- Asian Development Bank

Another prime reason for the success of ASEAN, which has gone low key, has been the role of Indonesia. Indonesia is perceived as a natural de facto leader of the International Organization of ASEAN since its establishment in 
1967 (Putri, 2015, p.188). The reasons which have made Indonesia, the natural leader of ASEAN are obvious. It may be the geographical size, population, size of the economy, possession of resources; Indonesia is far ahead of the rest of the ASEAN (Table 7). It is also important to note that, Indonesia is the only ASEAN member in the G20.

Table 7: ASEAN population and economy by country (2016)

\begin{tabular}{|l|c|c|c|c|}
\hline \multirow{2}{*}{ Country } & \multicolumn{2}{|c|}{ Population } & \multicolumn{2}{c|}{ Economy } \\
\cline { 2 - 5 } & In million & $\begin{array}{c}\text { \% share of } \\
\text { ASEAN }\end{array}$ & $\begin{array}{c}\text { GDP in } \\
\text { billion (USD) }\end{array}$ & $\begin{array}{c}\text { \% of total } \\
\text { ASEAN }\end{array}$ \\
\hline Brunei & 0.423 & 0.07 & 11.40 & 0.45 \\
\hline Cambodia & 15.762 & 2.47 & 20.02 & 0.78 \\
\hline Indonesia & $\mathbf{2 6 1 . 1 1 5}$ & $\mathbf{4 0 . 8 9}$ & $\mathbf{9 3 2 . 2 6}$ & $\mathbf{3 6 . 4 9}$ \\
\hline Laos & 6.758 & 1.06 & 15.90 & 0.62 \\
\hline Malaysia & 31.187 & 4.88 & 296.36 & 11.60 \\
\hline Myanmar & 52.885 & 8.28 & 67.43 & 2.64 \\
\hline Philippines & 103.320 & 16.18 & 304.90 & 11.94 \\
\hline Singapore & 5.607 & 0.88 & 296.97 & 11.62 \\
\hline Thailand & 68.864 & 10.78 & 406.84 & 15.93 \\
\hline Vietnam & 92.701 & 14.52 & 202.62 & 7.93 \\
\hline
\end{tabular}

Source: ASEAN economies infographic: comparison of ASEAN economies by nominal GDPhttps://aseanup.com/asean-infographics-population-market-economy/

Despite the overwhelming strength it possesses, its foreign policy has been designed in such a way it cooperates with the rest of ASEAN rather than dictating the terms. That's what has made Indonesia's role so unique. Looking at the economic aspect, Indonesia is a larger market for the ASEAN countries' exports. Indonesia also plays a vital role with regard to enhancing the regional integration process of ASEAN. In fact, improved role and leadership in politics and security, economy, socio-culture, and cooperation with dialogue partners in the process of integration of ASEAN community, was a strategic objective Ministry of Foreign Affairs of Indonesia which was expected to achieve from 2010 to 2014. Thus, Indonesia's leadership and role would always be vital for the success of ASEAN. 


\section{Findings and Suggestions}

Considering the information and statistics, the study found the positive relation between regional integration and economic success of individual states. Being in a regional grouping would make a country economically vibrant and stable. When it comes to regional economic integration, there are several factors which have to be taken in to consideration. To begin with, economic integration would have less stability and sustainability unless the regional groupings possess the below criteria. First and foremost, the members within a grouping should trust and understand each other. This is something which we see within ASEAN and do not see in SAARC.

When it comes to trade and investment, trade facilitation plays a pivotal role. Trade facilitation can be simply identified as all the steps that can be taken to smooth and facilitate the flow of trade (OECD, 2005). As the definition suggests trade facilitation is a key aspect of economic development and integration. Effective facilitation for trade and investment is pivotal for successful economic integration. When it comes to ASEAN, its desire to facilitate trade is reflected in a number of documents and agreement including ASEAN charter, ASEAN Vision 2025: Forging Ahead Together, ASEAN Economic Community Blueprint 2025, ASEAN Trade in Goods Agreement (ATIGA) etc. As described in ASEAN Trade in Good Agreement and the ASEAN Economic Community, ASEAN trade facilitation shall focus on the following areas.

i. Customs and Transport facilitation.

ii. Transparency of trade regulation and procedures.

iii. Standards and conformance

iv. Private sector engagement and business facilitation 
When it comes to South Asia, trade facilitation remains at a very poor level. This can be understood by referring the Table 8 .

Table 8: Number of documents required for import and export-2014

\begin{tabular}{|c|c|c|c|c|c|}
\hline \multicolumn{3}{|c|}{ South Asia } & \multicolumn{3}{|c|}{ Southeast Asia } \\
\hline Country & $\begin{array}{c}\text { No .of } \\
\text { documents } \\
\text { for import }\end{array}$ & $\begin{array}{c}\text { No. of } \\
\text { documents } \\
\text { for export } \\
\end{array}$ & Country & $\begin{array}{c}\text { No .of } \\
\text { documents } \\
\text { for import }\end{array}$ & $\begin{array}{c}\text { No. of } \\
\text { documents } \\
\text { for export } \\
\end{array}$ \\
\hline Afghanistan & 10 & 10 & Indonesia & 6 & 3 \\
\hline Bhutan & 11 & 9 & Myanmar & 8 & 8 \\
\hline India & 5 & 3 & Philippines & 7 & 6 \\
\hline Maldives & 9 & 7 & Singapore & 3 & 3 \\
\hline Nepal & 11 & 11 & Brunei & 5 & 5 \\
\hline Pakistan & 5 & 5 & Cambodia & 9 & 8 \\
\hline Sri Lanka & 7 & 7 & Lao PDR & 10 & 10 \\
\hline Bangladesh & 7 & 5 & Malaysia & 4 & 4 \\
\hline & & & Thailand & 5 & 5 \\
\hline & & & Vietnam & 8 & 5 \\
\hline Average & 8.1 & 7.1 & & 6.5 & 5.7 \\
\hline
\end{tabular}

Source: by author based on https://data.worldbank.org/indicator/IC.IMP.DOCS

Table 8 is a good example to show the differences exist between ASEAN and SARRC when it comes to facilitating trade. As given in the table, the average number of documents needed in SAARC region for import product is 8.1 while the corresponding figure for ASEAN is 6.5. Meanwhile, when it comes to exports the average number of documents needed in the SAARC region is 6.5 while the corresponding figure for ASEAN is 5.7. Looking at a country like Singapore, it requires a minimum number of documents for import-export procedures. In return, this has helped the country to enhance trade volumes and become successful in world trade.

Considering the level of economic integration which these regions have able to achieve, there is so much which SAARC should do to promote regional integration while ASEAN too has space to enhance regional integration. The study finds that much more can be achieved by ASEAN and SAARC 
working together. There are so much reasons and justifications that will encourage a SAARC-ASEAN platform. Some of the major reasons which support strengthening SAARC-ASEAN cooperation includes; geographical proximity and historical ties between the two regions, shared social and cultural identity, existence of SAARC and ASEAN, success attained by ASEAN, existing ASEAN-India relations, willingness of state leaders to work on a common platform and strong and resilient economic progress attained by the two regions. Among these positives, the willingness of state leaders is an encouraging factor for strengthening SAARC- ASEAN relations. No cooperation can be attained in any field unless the leaders are willing to commit for that. As far as strengthening SAARC-ASEAN relations are concerned, there is greater willingness from the side of state leaders in both the regions to strengthen ties with each other. Two of the best examples are the adaptation of Act East Policy by the current Indian premier Narendra Modi, and the speech delivered by the Prime Minister of Sri Lanka at the Indian Ocean Conference on $1^{\text {st }}$ September 2016, at Shangri La Hotel, Singapore.

Making his opening statement at the ASEAN-India Summit 2015, the Indian Prime Minister stated;

"As always, ASEAN is providing both inspiration and leadership for regional cooperation and integration. And from India's perspective, ASEAN values and leadership will remain central to integration across Asia and Pacific."

Delivering the inaugural address on "Global Power Transition and the Indian Ocean" at the recently concluded Indian Ocean conference, Sri Lankan premier told; 
"The cooperation and coordination between ASEAN and SAARC including Ramayana connection has given us strong cultural affinities. We have similar Governmental institutions and commercial practices. The English language is a link language. We have a huge cohort of youth more regionally conscious than their parents"

Furthermore, at the recently concluded $69^{\text {th }}$ sessions of the World Health Organization (WHO) regional committee of Southeast Asia, Ranil Wickremesinghe proposed a common health program for countries in South Asia and ASEAN states. He opined;

"ASEAN and SAARC can join together to set up one common health program because diseases in countries such as Cambodia may be common to Sri Lanka as well. We can get together and provide a better health service and better life for our people in our regions".

Against this backdrop, SAARC-ASEAN regional platform would be a better prospect in terms of strengthening and enhancing regional cooperation. SAARC in particular can be greatly benefitted through such an initiative.

\section{Summary and Conclusion}

Considering what has been discussed in the study, it is clear that regional economic integration boosts economic prosperity of both the region and individual states alike. As discussed, ASEAN countries have able to achieve great deal of success through integration. It can be trade, investment or tourism, ASEAN has done a commendable job as a regional grouping. Regional integration, as discussed should be dynamic, and ASEAN has been dynamic in its approach since its inception. It is moving forward. For example, as discussed they have widened the scope of integration from trade to investment and other areas. This is one major positive aspect which can be 
observed in ASEAN. ASEAN countries have greater understanding and cooperation compared to SAARC which is reflected by the volumes of intraregional trade, investments and tourist arrivals. As noted, one-fifth of ASEAN investments are made within ASEAN region. This is something SAARC has failed to do. Thus, in order to promote regional economic integration and yield results from that, any regional set up should focus on key areas like; mutual understanding and cooperation, connectivity, trade facilitation etc.

One key area which needs further study will be to discover areas where ASEAN and SAARC can work together. As said, leaders of the regions, SAARC in particular has understood the importance of these regional set ups working together. Thus, further study is required in that area. It can be a great platform for both regions, South Asia in particular to discover new paths and avenues of regional cooperation. As said before, people of both regions face identical issues, which need collective solutions. Thus, intraregional cooperation would certainly help both regions to be benefitted alike. Furthermore, intra-regional tourism has been one of the major aspects which have enhanced tourism in Southeast Asian countries. Thus further research can be carried out in how South Asia can promote intra-regional tourism as well.

\section{List of References}

2016 Economic Review Thailand (2017) Retrieved November 23, 2017, from Netherlands Embassy Bangkok website: https://www.netherlandsworldwide.nl/.../economic review Thailand 2016 ... Cached

ADB's Work to Support Regional Cooperation in Asia and the Pacific (2014) Retrieved August 26, 2016, from http://www.adb.org/themes/regional-cooperation/overview 
A journey towards regional economic integration : 1967 - 2017 (Rep.) (2017) Retrieved November 8, 2017, from ASEAN Secretariat, Jakarta. website: http://asean.org/storage /2017/09/ASEAN-50-Final.pdf

ADBI (2016) ASEAN 2030: Toward a Borderless Economic Community. Brookings Institution Press.

Kohli, H. S., Sharma, A., \& Sood, A. (Eds.) (2011) Asia 2050: realizing the Asian century. SAGE Publications India.

Visser, W., \& Tolhurst, N. (2017) The world guide to CSR: A country-by-country analysis of corporate sustainability and responsibility. Routledge.

Bhattacharyay, B. N. (2012) Benefits and challenges of integrating South and Southeast Asia. Retrieved from http://www.cesifo-group.de/DocDL/cesifo1_wp3819.pdf

Chowdhury, \&Mamta. (2005) Trade reforms and economic integration in south asia: SAARC to SAPTA. Applied Econometrics and International Development,5(4).

Hill, H., \&Menon, J. (2010) ASEAN Economic Integration: Features, Fulfillments, Failures and the Future (Working paper No. 69). Asian Development Bank.

Kher, P. (2012) Political economy of regional integration in south Asia (Tech. No. RVC 5). UNCTAD.

Kolovos, A. (2010) Regional Integration in East Asia (Master's thesis, Portland State University, 2010). Portland State University.

Kurlantzick, J. (2012) ASEAN's Future and Asian Integration (Working paper). Council on Foreign Relations.master plan on ASEAN connectivity 2025 (Rep.). (2016) the ASEAN Secretariat Jakarta. Retrieved November 23, 2017, from http://asean.org/storage /2016/09/ Master-Plan-on-ASEAN-Connectivity-20251.pdf

Meeting the Challenges in an Era of Globalization by Strengthening Regional Development Cooperation (Publication No. ST/ESCAP/2319). (2004) Economic and social commission for Asia and the Pacific: United Nations. 
Poli, E. (2014) Is the European Model Relevant for ASEAN? (Working paper No. 14). Istituto Affari Internazionali (IAI).

Putra, B. (2015) Indonesia's leadership role in ASEAN: history and future prospects. IJASOS- International E-Journal of Advances in Social Sciences, 1, 2nd ser., 188197.

Rahman, S. (2011) Same but Different?: Comparing the ASEAN and SAARC Frameworks (Working Paper No 123). National University of Singapore.

Regional Integration and Human Development: A Pathway for Africa (Rep.). (2011) United Nations Development Programme.

Roth, H. (2015) The Dynamics of Regional Cooperation in Southeast Asia (Working paper). GCSP.

Siddika, A. (2013) An overview of SAARC and ASEAN. IOSR Journal Of Humanities And Social Science (IOSR-JHSS), 14(5), 71-74. Retrieved November 8, 2017.

Tanaka, K. (2009) Regional Integration in Southeast Asia: Better Macroeconomic Cooperation Can Mitigate Risks (Working paper No. 90). OECD Development Centre.

The Costs and Benefits of Trade Facilitation (Issue brief). (2005) OECD. Retrieved November 23, 2017, from http://www.oecd.org/trade/facilitation/35459690.pdf

Trade and development report, 2007 (Rep. No. UNCT AD/TDR/2007). (2007, September 04) Retrieved August 26, 2016, from United Nations conference on trade and development website: http://unctad.org/en/docs//tdr2007_en.pdf

Travel \& tourism economic impact 2017 Indonesia (Rep.). (2017) Retrieved November 23, 2017, from world travel and tourism council website: https://www.wttc.org//media/files/reports/economic-impact-research/countries-2017/indonesia2017.pdf

Workman, D. (2017, February 06) Thailand's Top Trading Partners. Retrieved November 22, 2017, from http://www.worldstopexports.com/thailands-top-import-partners/ 